\title{
PHYSICAL METHODS OF PRE-PLANTING AND POSTHARVEST TREATMENT OF POTATO: A REVIEW
}

\author{
P.Yu. Kroupin ${ }^{1,2}$, O.G. Semenov ${ }^{3}$ \\ ${ }^{1}$ Russian State Agrarian University - \\ Moscow Timiryazev Agricultural Academy \\ Moscow, 127550, Russian Federation \\ ${ }^{2}$ Russian Research Institute of Agricultural Biotechnology \\ Moscow, 127550, Russian Federation \\ ${ }^{3}$ Peoples' Friendship University of Russia (RUDN University) \\ Moscow, 117198, Russian Federation \\ pavel-kroupin@yandex.ru
}

\begin{abstract}
Potato is an important staple food crop. Potato tubers require proper treatment before planting and after harvest to produce high yields and avoid storage losses. Among different techniques of potato treatment physical methods are of special interest: thermal treatment using hot water and steam, ultraviolet (including continuous-wave UV using pulsed Xe-lamps) and gamma-irradiation, treatment with magnetic and electromagnetic fields (including microwaves). The majority of physical methods is environmentally friendly and can be applied without special registration and in the developing countries. In the present paper, for the first time, the scientific papers on physical methods of potato treatment for the last 35 years are comprehensively reviewed. The review demonstrates that such an approach is perspective both for pre-planting and postharvest treatment of potato. Physical treatment affects biochemical, cellular and physiological status of potato. Methods of physical treatment enable to control phytopathogens, and some methods (ultraviolet and gamma-radiation) even are capable of improving immunity of plants. The main traits of potato tubers that can be influenced by physical treatment are sprouting (stimulation or inhibition), susceptibility to rot and black leg diseases, and starch, reducing sugars and ascorbic acid contents. The tuber response to physical treatment depends on dosage and date of treatment, duration and temperature of storage, agricultural technology and cultivar. Low doses of treatment may be inefficient while too high dosage may result in cell deterioration or death and poor immunity, and eventually to disease development. Too early treatment may damage a tuber since it should pass through suberization (wound healing) after harvest; too late treatment requires higher doses. The proper adjustment of treatment is necessary for cultivar and individual storage conditions.
\end{abstract}

Key words: potato, physical treatment, hydrothermal treatment, steam, ultraviolet, xenon lamp, gamma-irradiation, electromagnetic microwaves, phytopathogen

\section{INTRODUCTION}

Potato tubers require proper treatment before planting, after harvesting and at storage to produce high yields and avoid storage losses. Different methods are used to reduce infection, promote sprouting or keep dormancy, maintain required physiological and biochemical status of a tuber.

There are different methods of potato tuber treatment, such as chemical, biological, breeding, and physical; application of them is determined by the aim and the cost 
of technique. Physical treatment does not require complicated technologies such as chemical synthesis or development of new potato varieties or new bacteria strains and can be afforded by developing economies. In addition, it is ecological friendly and does not affect consumer health. Then, some physical methods may be competitive to genetic and chemical modifications as they do not require registration or special permission and may be more effective in certain aspects. On the other hand, such practices as hot dry, steaming, UV and gamma radiation are far from introduction at industrial scale as technologies and are still perspective and promising approaches. Moreover, each physical method if applied at improper dosage can damage or even kill a tuber so it is crucial to find a proper time and dose in each case depending on the aim of treatment and cultivar.

The aim of this paper is to review the achievements in physical treatment methods of potato.

\section{TEMPERATURE TREATMENT}

Hot water treatment of potato tubers significantly reduces rot bacteria contamination [1]. Mackay and Shipton [2] did not detect Pectobacterium atrosepticum and $P$. carotovorum subsp. carotovorum in tuber peel after dipping naturally infected potato tubers for $10 \mathrm{~min}$ in water at $55{ }^{\circ} \mathrm{C}$ as well as no blackleg symptoms were observed in plants grown from the treated tubers. Similarly, Wale and Robinson [3] and Shirsat et al. [4] showed that periderm and lenticels contamination can be significantly reduced by incubation in water at $44{ }^{\circ} \mathrm{C}$ for $30 \mathrm{~min}$ or at $56{ }^{\circ} \mathrm{C}$ for $5 \mathrm{~min}$. However, if insufficiently dried out, the tubers may rot due to multiplication of survived bacteria. Drying tubers under forced ventilation with air knives may help to overcome this problem not only removing water from tuber surface but also keeping heat [5]. Hydrothermal treatment helps to control several fungal pathogens causing gangrene, skin spot, silver and black scab [6]. Abbas et al. [7] showed that treatment of tubers with hot water at $37{ }^{\circ} \mathrm{C}$ for 2-3 hours reduces Potato Leaf Roll Virus in plants grown from them by up to $37 \%$. However, hydrothermal treatment may lead to delay in sprouting or even death of tuber depending on the physiological state and eventually to yield losses [1].

Steam can be used as an alternative to hot water to control fungi and bacteria especially $P$. atrosepticum and $P$. carotovorum present in tuber periderm. Steam treatment reduced periderm contamination from $26 \ldots 59 \%$ to $1 \ldots 3 \%$ [8]. Bartz and Kelman [9] observed that external population can be eliminated by hot air dry at $50{ }^{\circ} \mathrm{C}$. Hot air dries tubers and stimulates wound healing without affecting subsequent sprouting. However, longer incubation time required for steam treatment compared to hot water can adversely affect a tuber [1].

Lavrova et al. [10] studied the effect of pre-planting cool treatment on seed tubers artificially infected with nematodes: sprouted tubers were kept at $+5{ }^{\circ} \mathrm{C}$ for 2 hours during 6 days. As a result, yield quantity and quality (starch and ascorbic acid content) were improved when potato was grown on infested soils. Eremeev et al. [11] showed that pre-planting heat shock at $30{ }^{\circ} \mathrm{C}$ for 2 days with subsequent keeping at $+12 \ldots$ $+15{ }^{\circ} \mathrm{C}$ for 5 days in the light make it possible to get more tubers $5-10$ days earlier than in the control that may be explained by increasing physiological age of the seed tubers. 


\section{SHORT-WAVELENGTH ULTRAVIOLET IRRADIATION}

Short-wavelength ultraviolet light (UV-C) has strong antimicrobial effect. It provokes single and double-strand breaks in DNA, producing thymine dimmers and 4,6photoproduct as well as reactive oxygen species. The resulted DNA lesions interfere with replication and transcription, eventually disabling or killing microorganisms [12 - 15]. Additionally, the UV-C light results in tryptophan, tyrosine, phenylalanine and cysteine oxidation with subsequent degradation and DNA-protein bonds that inhibit cell survival and proliferation [16].

The UV-C rays cover the wavelength range $100-280 \mathrm{~nm}$, in practice mercuryvapor lamps (Hg-lamps) with a strong emission line at $254 \mathrm{~nm}$ are widely used for disinfection purposes. The UV-C energy is unable to penetrate tuber tissue to reach the vascular pathogens and therefore can be used for surface microorganisms mainly [1].

The UV-C irradiation at $10 \mathrm{~kJ} \mathrm{~m}^{-2}$ reduces incidence and severity of common scab by $28 \%$ and $62 \%$, respectively, while silver scab is inhibited at $15 \mathrm{~kJ} \mathrm{~m}^{-2}$ by $22 \%$ and $36 \%$, respectively [17]. Ranganna et al. [18] demonstrated that UV-C irradiation at $15 \mathrm{~kJ} \mathrm{~m}^{-2}$ inhibits soft and dry rot in the tubers inoculated with Fusarium solani and $P$. carotovorum at $+8{ }^{\circ} \mathrm{C}$ for 3 months. However, the inhibition efficiency of UV-C dropped at longer inoculation of the tubers. Rocha et al. [19] observed that the UV-C treatment at $34.5 \mathrm{~kJ} \mathrm{~m}^{-2}$ significantly reduced postharvest soft rot incidence by $60 \%$ in potato seed tubers stored at $+25{ }^{\circ} \mathrm{C}$ for 9 days after inoculation with $P$. carotovorum subsp. carotovorum. However, the disease was completely inhibited both in untreated and UV-C-treated tubers when they were stored under fluorescent light $(280 \ldots 400 \mathrm{~nm}$, UV-A + UV-B; $1.6 \mu \mathrm{mol} \mathrm{m} \mathrm{m}^{-2} \mathrm{~s}^{-1}$ ). The disease inhibition may be associated with the accumulation of $\alpha$-solanine and $\alpha$-chocanine glycoalkaloids in periderm and flesh in UV-C- and fluorescent light treated tubers. Thus, the UV-C irradiation affects not only surface microorganisms but also tuber periderm layer changing its biochemical status, thus enhancing its immunity.

Besides disinfection of tubers the UV-C treatment can be used for potato tuber dormancy regulation at storage. Conventionally, low positive temperatures and ethylene are used to inhibit sprouting, but these techniques can give rise to high sugar concentrations reducing the processing quality of potatoes [20-22]. Cools et al. [23] demonstrated that sprouting inhibition in response to the UV-C treatment is cultivar specific. Tuber sprouting of the most sensitive to UV-C irradiation cultivars was inhibited at $10 \mathrm{~kJ} \mathrm{~m} \mathrm{~m}^{-2}$ and associated with increase in ascorbic acid level; the strongest effect appeared at 10\% eye movement. However, even at such high dose as $30 \mathrm{~kJ} \mathrm{~m}^{-2}$ authors did not find sprouting stimulation as it was observed in other experiments [9, 24, 25]. The UV-C treatment at $3.4 \ldots 13.6 \mathrm{~kJ} \mathrm{~m}^{-2}$ significantly reduced number of spouts in the irradiated tubers if stored at $+20^{\circ} \mathrm{C}$ for up to 20 days [26].

The UV-C treatment can affect biochemical parameters of tubers. Hg-lamp irradiation at $15 \mathrm{~kJ} \mathrm{~m}^{-2}$ changed neither texture nor color of a tuber as well as did not damage starch granules [25]. Cools et al. [23] did not found DNA degradation or cyclobutane pyrimidins in periderm of the tubers irradiated at $5 \ldots 30 \mathrm{~kJ} \mathrm{~m}^{-2}$. The total reducing sugar content in the UV-C-treated tubers was $1.65 \ldots 2.02$ fold lower compared to the 
untreated control after storage at $+4{ }^{\circ} \mathrm{C}$ for 28 days. Lin et al. [27] suggest that the $\mathrm{UV}-\mathrm{C}$ treatment possibly regulates the gene cascade in potato tuber (sucrose phosphate synthase, invertase inhibitor $1 / 3$, and invertase 1) that reduced accumulation of reducing sugars and prevented oxidative injury in potato cells.

\section{CONTINUOUS-WAVE ULTRAVIOLET RADIATION}

Mercury-free pulsed xenon lamp (Xe-lamps) can be used as an alternative to $\mathrm{Hg}$ lamp. Xe-lamp is characterized by continuous emission spectrum (190 ... $400 \mathrm{~nm}$, i.e. UV-A, UV-B and UV-C) that provides bactericide effect to the irradiated objects independent from the absorption spectrum at a shorter exposition time compared to Hg-lamp. The efficiency of the continuous-wave pulsed UV-light was proved for water disinfection $[28,29]$. The advantages of Xe-lamps allow them to be widely used for disinfection purposes in different spheres: food production and storage [30, 31], disinfection of surfaces [32], and packaging [33].

To estimate the Xe-lamp irradiation effect on the integrity of DNA of Dickeya solani, pathogen causing potato blackleg, Kroupin et al. [34] performed quantitative polymerase chain reaction (qPCR). It was shown that each genomic $100 \mathrm{bp}$ is damaged by $\sim 10 \mathrm{~J} \mathrm{~m}^{-2}$. The comparison of bactericide effects of $\mathrm{Hg}$ - and Xe-lamps demonstrated that Xe-lamp damages $4.9 \%$ of $D$. solani genome at $10 \mathrm{~kJ} \mathrm{~m}^{-2}$ while $\mathrm{Hg}$-lamp only $1.5 \%$ at the same dose; unlike Hg-lamp, Xe-lamp irradiation resulted in protein degradation and aggregation [35]. The experiments on potato slices showed that Xe-lamp irradiation at $12 \mathrm{~kJ} \mathrm{~m}^{-2}$ almost totally inhibited the rot development while Hg-lamp irradiation even at $36 \mathrm{~kJ} \mathrm{~m}^{-2}$ resulted in the rot spot diameter three fold larger than that in the Xelamp variant $[36,37]$. Further study of Xe-lamp irradiation may show its perspective in controlling pathogens as well as its effect on physiological and biochemical status of potato tubers.

Both UV-C and continuous-wave UV-irradiation can be used not only for tuber treatment but also for hygienic measures such as disinfection of irrigation water, machines and tools, storage and package.

\section{GAMMA IRRADIATION}

High-energy ionizing radiation affects enzyme activity, protein synthesis, metabolic processes in the cell, cell division, differentiation, hormone balance and gas exchange. As a result, considerable changes can occur in the tuber dormancy, starch, sugar and ascorbic acid content and, eventually, technological and custom properties of the tuber. Depending on the dose gamma irradiation may either induce or inhibit metabolic processes in the tuber, having some antimicrobial effect.

\section{Stimulation effect of low gamma irradiation doses}

Low doses of gamma radiation can be used for potato in vitro propagation to stimulate tuber formation. Al-Safadi et al. [38] found that irradiation at 2.5 Gy simulates microtuber production in vitro by up to $38 \%$ in comparison to untreated plantlets without fear of genetic changes in the used cultivars. Li et al. [39] demonstrated that irradiation 
of the potato plantlets in vitro significantly stimulated microtuberization by $116.7 \%$ and $34.5 \%$ in the studied cultivars compared to the non-irradiated control and increase in fresh mass. Low doses (2 ... 3 Gy) increased starch content; medium doses (4 ... 6 Gy) increased protein content; higher doses $(6 . .8 \mathrm{~Gy})$ increased ascorbic acid and reducing sugars in microtubers.

Moderate doses can be applied to stimulate sprouting of tubers with low germination ability, e.g. in maintenance of genetic stocks. Salomon et al. [40] demonstrated the stimulation effect of $20 \mathrm{~Gy}$ on germination of botanical seeds while Tikhonov et al. [41] observed the stimulation effect of 50 Gy on seed tubers.

\section{Inhibiting effect of high gamma irradiation doses}

The main goal of storage is to keep dormancy as close to postharvest level as it is possible. Second task is to keep starch content at the initial level. The sprout of tuber buds enhances respiration and induces enzymatic hydrolysis of the starch. Low temperature inhibits sprouting but results in accumulation of reducing sugars ('cold-induced sweetening'), which induce discoloration of potato chips or French fries [42]. Ionizing irradiation inhibits sprouting without using low temperatures at storage. It is especially critical for south regions with warm postharvest seasons. The third task is to keep tubers free from rot during storage period. Moderate gamma-irradiation doses may promote immunity response in the tuber, while too high doses may damage tissues and result in tuber rot.

The recommended gamma irradiation dose for sprout suppression varies from $40 \ldots 50$ Gy to $120 \ldots 150$ Gy [43-47]. The dose sufficient for sprout inhibition is apparently cultivar specific. For example, the total inhibition in cv. Lorkh and cv. Lyubava tubers was observed at dose higher than $18 \mathrm{~Gy}$ and $21 \mathrm{~Gy}$, respectively [48].

Moderate gamma irradiation inhibits rot and scab severity. Tikhonov et al. [41] observed inhibition of silver scab after gamma irradiation at $100 \mathrm{~Gy}$, whereas dose increase up to 150 Gy resulted in the development of common scab, silver scab and ring rot that may be explained by the inhibition of the tuber cell immunity at higher doses. Afify et al. [49] demonstrated that 50 Gy inhibits sprouting without causing rot that may be associated with high antioxidant enzyme activities (peroxidase, polyphenol oxidase, glutathione-S-transferase, superoxide dismutase, and catalase) and the lowest level of lipid peroxidaiton. Mahto et al. [46] suggests that the rot suppression at $150 \mathrm{~Gy}$ may be due to higher polygalacturonase-inhibiting protein activity in non-sprouted tubers compared to the sprouted tubers.

At higher gamma irradiation doses the cell wall and membrane are disrupted; rot development, water loss, skin and flesh darkening, bud blackening and tuber softening are observed. In most studies the destructive processes are shown at doses higher than $1 \mathrm{kGy}[44,50,51]$. Apparently, $500 \mathrm{~Gy}$ is the highest acceptable (threshold) dose and depends on the cultivar and tuber condition $[46,47]$. Since bud tissues in eyes are meristematic and are least tolerant to gamma irradiation, their blackening occurs at 500 Gy [46]. Tuber lots with high rot potential may not be suitable for gamma irradiation treatment at all [43]. 
The date of tuber treatment (days after harvest, DAH) is critical: periderm is very susceptible to high irradiation doses immediately after harvesting and tuber should pass through suberization. The day of treatment influences the accumulation of sugars in tuber. Dhali et al. [47] showed that 150 Gy 15 DAH resulted in less sugar accumulation during 2 months of storage rather than treatment $30 \mathrm{DAH}$. Rezaee et al. [45] demonstrated that the later the treatment $(10,30$ and $50 \mathrm{DAH}$ were compared), the more sugar is accumulated after 5 months of storage both at $+8{ }^{\circ} \mathrm{C}$ and $+16{ }^{\circ} \mathrm{C}$. After 120 days of storage tubers irradiated $5 \mathrm{DAH}$ contained less reducing sugars than that $30 \mathrm{DAH}$ [50].

The day of treatment determines the dose of gamma irradiation: the latter the treatment the higher dose is required. Treatment at low dose (40 Gy) on 6 DAH inhibits sprouting stronger and does not accompanied with shriveling compared to treatment on day 30 after harvest; treatment at both 80 and 120 Gy 5 and 30 DAH showed good tuber appearance [50]. Rezaee et al. [45] showed that treatment 10 DAH totally inhibits sprouting at $100 \mathrm{~Gy}$; the irradiation dose for treatment 30 and $50 \mathrm{DAH}$ should be raised up to $150 \mathrm{~Gy}$. Dhali et al. [47] observed that weight loss of tubers irradiated $15 \mathrm{DAH}$ is less than $30 \mathrm{DAH}$ (150 Gy, 2 month of storage).

Temperature of storage is crucial since it is gamma irradiation make it possible to store potato tubers at moderate-to-high temperatures without accumulation of reducing sugars as it happens at low temperature storage. The higher the temperature of storage, the less sugar is accumulated in tubers. Dhali et al. [47] showed that tubers exposed to $150 \mathrm{~Gy}$ and subsequently stored at $+6{ }^{\circ} \mathrm{C}$ for 2 months contained more sugars compared to $+15^{\circ} \mathrm{C}$. Rezaee et al. [45] found that tubers irradiated at $100 \mathrm{~Gy}$ and subsequently stored at $+8{ }^{\circ} \mathrm{C}$ accumulated more sugars than that at $+16{ }^{\circ} \mathrm{C}$. Ezekiel et al. [52] demonstrated the response to the storage temperature was cultivar specific: $\mathrm{cv}$. Kufri Jyoti contained less reducing sugars at $+16^{\circ} \mathrm{C}$ than at $+8{ }^{\circ} \mathrm{C}$ by $34 \%$, whereas cv. Kufri Chandramukhi by 15\% (150 Gy, 90 days of storage). Rezaee et al. [45] suggests that less sugar content at higher storage temperature may be due to higher respiration rates. In addition, temperature influences weight loss: weight loss was higher if tubers were stored at $+16{ }^{\circ} \mathrm{C}$ than at $+8{ }^{\circ} \mathrm{C}(100 \mathrm{~Gy}, 5$ months of storage); these losses can be compensated by dose increase to $150 \mathrm{~Gy}$.

Gamma irradiation may affect the integrity of starch granules and amylose and amylopectin molecules and the response of the cell may be cultivar specific [50, 52]. Ezekiel et al. [52] showed that the degradation of starch and, as a consequence, changes in sugar accumulation and amylose content after irradiation at $500 \mathrm{~Gy}$ was specific for each of three cultivars studied. Mahto et al. [46] found that cv. Kufri Sindhuri is characterized by increase in the textural parameters after irradiation at $500 \mathrm{~Gy}$ and storage at $+12{ }^{\circ} \mathrm{C}$ for 120 days compared to cv. Kufri Jyoti. Cell wall remained rigid, accounting for higher textural values registered after treatment at $120 \mathrm{~Gy}$ and storage at $+22{ }^{\circ} \mathrm{C}$ for 4 months; exposition to $1 \mathrm{kGy}$ induced damage and resulted in more collapsed cells with less rigid cell walls [50].

The dose of gamma-irradiation affects the ascorbic acid content in tubers. The increase in irradiation dose resulted in drop in ascorbic acid in tubers when stored at $+15^{\circ} \mathrm{C}$ and $+16^{\circ} \mathrm{C}$, respectively $[45,47]$. 
Gamma irradiation leads to rise in amylose content $[52,53]$. Lu et al. [53] suggests that it may be associated with the effect of gamma-rays on the branched molecules of amylopectin susceptible to low radiation dosage; the newly de-branched amylopectin chains contributed to the amylose content. At extreme dosage both amylose and amylopectin molecules are depolymerized and thus the starch shows the decreased amylose content $[54,55]$. Tubers exposed to $150 \mathrm{~Gy}$ and stored at $+24{ }^{\circ} \mathrm{C}$ for 35 days showed the starch content at the level of the untreated control [51]. Lu et al. [53] showed that starch content significantly decreased in two studied cultivars irradiated at $100 \mathrm{~Gy}$ and stored at $+8{ }^{\circ} \mathrm{C}$ for 5 months.

Irradiation dose affects sugar content in tubers: the higher radiation, the higher sugar content. Apparently, sugar molecules are a product of starch glycoside bonds breakage by gamma-rays [54]. Frazier et al. [43] demonstrated that a dramatic raise in sugar content occurs after irradiation at $20 \ldots 40$ Gy and storage at $+7.2{ }^{\circ} \mathrm{C}$; then the sugar content is normalized to the untreated control level in 210 days if stored at $+7.2^{\circ} \mathrm{C}$ or in a month if stored at $+15^{\circ} \mathrm{C}$. The content of reducing sugars in tubers exposed to $1 \mathrm{kGy}$ was 1.3 fold lower than at $80 \mathrm{~Gy}$ when stored at $+22^{\circ} \mathrm{C}$ for 120 days [50]; glucose content in tubers at $2 \mathrm{kGy}$ was 1.8 fold higher than at $150 \mathrm{~Gy}$ when stored at $+24{ }^{\circ} \mathrm{C}$ for 35 days. The glucose content dynamics through storage is cultivar specific: raise in glucose content in tubers of cv. F03031 and F03028 exposed to 100 Gy and stored at $+8{ }^{\circ} \mathrm{C}$ was 1.5 and 2 fold, respectively; cv. Shepody did not show significant changes in glucose content [53]. Tubers of cv. Kufri Jyoti and cv. Kufri Chandramukhi treated at 500 Gy and stored at $+16{ }^{\circ} \mathrm{C}$ contained $20 \%$ and $5 \%$ reducing sugars more than at $100 \mathrm{~Gy}$, respectively.

Thus, the gamma irradiation treatment of potato tubers at moderate dosage (40 ... 150 Gy) should be thoroughly optimized. The main advantages of gamma irradiation are the inhibition of sprouting, the opportunity to store treated tubers at moderate $(15 \ldots$ $22{ }^{\circ} \mathrm{C}$ ) temperature and rot and scab control. On the other hand, the increase in dose results in raise in reducing sugar and amylose content, loss in starch and ascorbic acid content, drop in weight mass and specific gravity, rot development due to cell structure damage. The dosage, date of treatment (day after harvest), and temperature should be properly adjusted depending on a particular cultivar and storage duration.

\section{MAGNETIC AND ELECTROMAGNETIC TREATMENT}

Magnetic field can be used for tuber disinfection to promote sprouting of seed tubers and for postharvest treatment.

Pre-planting electromagnetic microwave irradiation of seed tubers at $10 \mathrm{~kJ} \mathrm{~m} \mathrm{~m}^{-2}$ decreased significantly the incidence of round rot in the yield by $35 \%$; irradiation at $1 \mathrm{~kJ} \mathrm{~m}^{-2}$ inhibited strongly common and silver scab incidences by $30 \%$ and $28 \%$ and severity by $40 \%$ and $11 \%$, respectively. Postharvest treatment at $15 \mathrm{~kJ} \mathrm{~m}^{-2}$ reduced the incidence of round rot by $80 \%$ whereas $6 \mathrm{~kJ} \mathrm{~m}^{-2}$ did not affect the disease incidence [17].

Marks et al. [56] observed stimulation of length and number of stems, foliage and stem mass, and tuber sprouting index by canopy treatment with variable magnetic field. 
Tikhonov et al. [17] found that small dosage of electromagnetic microwaves stimulated growth of sprouts that became more competitive to parasitic mycelium. Vasiliev et al. [57] showed the effect of electromagnetic microwave field on yield and starch content in tubers; the effect depended on the agricultural techniques used in the field experiments. The dosage of variable electromagnetic field affects the losses of tuber weight during storage at $+25{ }^{\circ} \mathrm{C}$ for 16 days: the losses at $6 \ldots 8 \mathrm{mTs}$ did not exceed $20 \%$ whereas at higher doses they raised to $75 \%$ compared to $39 \%$ in the untreated control [58].

\section{OTHER PHYSICAL TREATMENTS}

There are other perspective methods of potato tuber treatment studied in papers: helium plasma [59], treatment with modulated low-frequency electric field [60] and others.

\section{CONCLUSIONS}

In conclusion, the following physical treatment approaches have been studied for the last 35 years: steam and hot water, ultraviolet (UV-C and continuous-wave UV) and gamma irradiation, magnetic field. High-temperature treatment with hot water or steam can be used mainly to control blackleg. Treatment with high frequency waves (microwaves, gamma and ultraviolet irradiation) is characterized by more complex effect on tuber: disinfection (especially blackleg, scab and rot), immunity enhancing/suppression, sprouting stimulation/suppression, changes/maintenance of biochemical compounds content. The crucial parameters for physical field treatment are the proper adjustment of the dosage, date and storage conditions. Too low dosage may be insufficient to suppress pathogens, while too high dosage may result in cell wall damage and starch degradation that leads to rots and losses. A special attention should be paid to the influence of treatment on tuber dormancy: sprout stimulation is required for pre-planting treatment while postharvest treatment should inhibit sprouting. Finally, since UV and gamma irradiation are cultivar specific, the treatment technology should be finely adjusted for each cultivar depending on the conditions of growing and storage.

\section{ACKNOWLEDGMENT}

The work is financially supported in the frames of State Task of Federal Agency of Scientific Organization of Russia № 0574-2018-006.

\section{REFERENCES}

1. Czajkowski R, Perombelon MC, van Veen JA, van der Wolf JM. Control of blackleg and tuber soft rot of potato caused by Pectobacterium and Dickeya species: a review. Plant Pathology. 2011; 60(6):999—1013. Available from: doi: 10.1111/j.1365-3059.2011.02470.x.

2. Mackay JM, Shipton PJ. Heat treatment of seed tubers for control of potato blackleg (Erwinia carotovora subsp. atroseptica) and other diseases. Plant Pathology. 1983; 32(4):385-393. Available from: doi: 10.1111/j.1365-3059.1983.tb02852.x. 
3. Wale SJ, Robinson K. Evaluation of large scale hot water dipping and forced ventilation of seed potatoes to reduce tuber contamination with blackleg bacteria (Erwinia spp). In: British Crop Protection Conference - Pests and Diseases. Proceedings of a Conference Held at Brighton Metropole; 1986 Nov 17-20; Brighton, England. Brighton: BCPC Publications; 1986. p. $1137-1143$.

4. Shirsat SG, Thomas P, Nair PM. Evaluation of treatments with hot water, chemicals and ventilated containers to reduce microbial spoilage in irradiated potatoes. Potato Research. 1991; 34:227-231. Available from: doi: 10.1007/BF02358046.

5. Pérombelon MCM, Burnett EM, Melvin JS, Black S. Preliminary studies on the control of potato blackleg by a hot water treatment of seed tubers. In: Tjamos EC, Beckman CH. (eds.) Vascular Wilt Diseases of Plants: Basic Studies and Control. Proceedings of the NATO Advanced Research Workshop on the Interaction of Genetic and Environmental Factors in the Development of Vascular Wilt Diseases; 1988; Athens, Greese. New York: SpringerVerlag; 1989. p. 557—566. Available from: doi: 10.1007/978-3-642-73166-2_44.

6. Dashwood EP, Burnett EM, Perombelon MC. Effect of a continuous hot water treatment of potato tubers on seed-borne fungal pathogens. Potato Research. 1991; 34(1):71-78. Available from: doi: 10.1007/BF02358097.

7. Abbas A, Arif M, Ali A. Use of hot water-thermotherapy to free potato tubers of potato leaf roll virus (PLRV). International Journal of Life Sciences Scientific Research. 2016; 2(2):155-162.

8. Afek U, Orenstein J. Disinfecting potato tubers using steam treatments. Canadian Journal of Plant Pathology. 2002; 24(1):36 - 39. Available from: doi: 10.1080/07060660109506968.

9. Bartz JA, Kelman A. Effect of air-drying on soft rot potential of potato tubers inoculated by immersion in suspensions of Erwinia carotovora. Plant disease. 1985; 69:128-131. Available from: doi: 10.1094/PD-69-128.

10. Lavrova VV, Matveeva EM, Sysoeva MI. Short pre-sowing treatment of potato tubers with low temperature to suppress Globodera rostochiensis invasion. Sel'skokhozyaistvennaya Biologiya [Agricultural Biology]. 2014; (1):98-102. (In Russ). Available from: doi: 10.15389/agrobiology.2014.1.98eng.

11. Eremeev V, Lohmus A, Laaniste P, Joudu J, Talgre L, Lauringson E. The influence of thermal shock and pre-sprouting of seed potatoes on formation of some yield structure elements. Acta Agriculturae Scandinavica, Section B - Plant Soil Science. 2008; 58(1):35-42. Available from: doi: 10.1080/09064710601160243.

12. Sinha RP, Hader DP. UV-induced DNA damage and repair: a review. Photochemical and Photobiological Sciences. 2002; 1(4):225-236. Available from: doi: 10.1039/B201230H.

13. Rolfsmeier ML, Laughery MF, Haseltine CA. Repair of DNA Double-strand breaks following UV damage in three Sulfolobus solfataricus strains. Journal of Bacteriology. 2010; 192(19): 4954 -4962. Available from: doi: 10.1128/JB.00667-10.

14. Epshtein V, Kamarthapu V, McGary K, Svetlov V, Ueberheide B, Proshkin S, et al. UvrD facilitates DNA repair by pulling RNA polymerase backwards. Nature. 2014; 505:372 - 377 . Available from: doi: 10.1038/nature12928.

15. Cadet J, Grand A, Douki T. Solar UV radiation-induced DNA bipyrimidine photoproducts: formation and mechanistic insights. Topics in Current Chemistry. 2014; 356:249-275. Available from: doi: 10.1007/128_2014_553.

16. Neves-Petersen MT, Gajula GP, Petersen SB. UV light effects on proteins: from photochemistry to nanomedicine. In: Saha S. (ed.) Molecular Photochemistry: Various Aspects. London: IntechOpen; 2012. p. 125-158. Available from: doi: 10.5772/37947.

17. Tikhonov AV, Tsygvintsev PN, Tikhonov VN. The effect of gamma, UV and microwave radiation on potato tubers. In: Zhevora SV. (ed.) Kartofelevodstvo. Proceedings of scientificpractical conference "Modern Technologies of production, storage and processing of potato"; 2017; Lorch Potato Research Institute. Moscow: Lorch Potato Research Institute; 2017. p. 300 306. (In Russ). 
18. Ranganna B, Kushalappa AC, Raghavan GSV. Ultraviolet irradiance to control dry rot and soft rot of potato in storage. Canadian Journal of Plant Pathology. 1997; 19(1):30-35. Available from: doi: 10.1080/07060669709500568.

19. Rocha AB, Honório SL, Messias CL, Otón M, Gómez PA. Effect of UV-C radiation and fluorescent light to control postharvest soft rot in potato seed tubers. Scientia Horticulturae. 2015; 181:174-181. Available from: doi: 10.1016/j.scienta.2014.10.045.

20. Sowokinos JR. Biochemical and molecular control of cold-induced sweetening in potatoes. American Journal of Potato Research. 2001; 78(3):221-236. Available from: doi: 10.1007/BF02883548.

21. Daniels-Lake BJ, Prange RK, Nowak J, Asiedu SK, Walsh JR. Sprout development and processing quality changes in potato tubers stored under ethylene: 1. Effects of ethylene concentration. American Journal of Potato Research. 2005; 82(5):389-397. Available from: doi: 10.1007/BF02871969.

22. Foukaraki SG, Cools K, Chope GA, Terry LA. Effect of the transition between ethylene and air storage on post-harvest quality in six UK-grown potato cultivars. The Journal of Horticultural Science and Biotechnology. 2014; 89(6):599-606. Available from: doi: 10.1080/14620316.2014.11513126.

23. Cools K, Alamar MDC, Terry LA. Controlling sprouting in potato tubers using ultraviolet-C irradiance. Postharvest Biology and Technology. 2014; 98:106-114. Available from: doi: 10.1016/j.postharvbio.2014.07.005.

24. Ranganna B. Thermal treatments for short-term storage of potato (Solanum tuberosum L.) [Dissertation]. Quebec: Department of Agricultural and Biosystems Engineering Macdonald Campus of McGill University; 1996.

25. Ranganna B, Kushalappa AC, Raghavan GSV. Ultraviolet irradiance to control dry rot and soft rot of potato in storage. Canadian Journal of Plant Pathology. 1997; 19(1):30-35. Available from: doi: 10.1080/07060669709500568.

26. Pristijono P, Bowyer MC, Scarlett CJ, Vuong QV, Stathopoulos CE, Golding JB. Effect of UV-C irradiation on sprouting of potatoes in storage. Acta Horticulturae. 2018; 1194:475 - 478. Available from: doi: 10.17660/ActaHortic.2018.1194.69.

27. Lin Q, Xie Y, Liu W, Zhang J, Cheng S, Xie X et al. UV-C treatment on physiological response of potato (Solanum tuberosum L.) during low temperature storage. Journal of food science and technology. 2017; 54(1):55-61. Available from: doi: 10.1007/s13197-016-2433-3.

28. Wang T, MacGregor SJ, Anderson JG, Woolsey GA. Pulsed ultra-violet inactivation spectrum of Escherichia coli. Water Research. 2005; 39(13):2921-2925. Available from: doi: 10.1016/j.watres.2005.04.067.

29. Bohrerova Z, Shemer H, Lantis R, Impellitteri CA, Linden KG. Comparative disinfection efficiency of pulsed and continuous-wave UV irradiation technologies. Water Research. 2008; 42(12):2975-2982. Available from: doi: 10.1016/j.watres.2008.04.001.

30. Gomez-Lopez VM, Ragaert P, Debevere J, Devlieghere F. Pulsed light for food decontamination: a review. Trends in Food Science and Technology. 2007; 18(9):464 473. Available from: doi: 10.1016/j.tifs.2007.03.010.

31. Ignat A, Manzocco L, Maifreni M, Bartolomeoli I, Nicoli MC. Surface decontamination of fresh-cut apple by pulsed light: Effects on structure, colour and sensory properties. Postharvest Biology and Technology. 2014; 91:122-127. Available from: doi: 10.1016/j.postharvbio.2014.01.005.

32. Levy C, Aubert X, Lacour B, Carlin F. Relevant factors affecting microbial surface decontamination by pulsed light. International Journal of Food Microbiology. 2012; 152(3):168 - 174. Available from: doi: 10.1016/j.ijfoodmicro.2011.08.022.

33. Turtoi M, Nicolau A. Intense light pulse treatment as alternative method for mould spores destruction on paper - polyethylene packaging material. Journal of Food Engineering. 2007; 83(1):47-53. Available from: doi: 10.1016/j.jfoodeng.2006.11.017. 
34. Krupin PY, Yaremko AB, Panycheva YS, Tumashevich KA, Orynbaev AT, Mazurin ES, Divashuk MG. Approbation of a set of reagents to detect Dickeya solani for the quantitative assessment of DNA damage caused by the impulsed xenon lamp. Izvestiya Timiryazevskoi Sel'skokhozyaistvennoi Akademii. 2018; (2):34-47. (In Russ). Available from: doi: 10.26897/0021-342X-2018-2-34-48.

35. Krupin PY, Yaremko AB, Bazhenov MS, Kamrukov AS, Tumashevich KA, Bagrov VV, Panycheva YS, Mazurin ES, Divashuk MG. Comparison of the effect of ultraviolet radiation of a low-pressure mercury lamp and a pulsed xenon lamp on the genome and proteome of Dickeya solani. Potato and Vegetables. 2017; (10):26-29. (In Russ).

36. Krupin PY, Mazurin ES, Kamrukov AS, Yaremko AB, Tumashevich KA, Panycheva YS, Alekseev YI, Divashuk MG. The impact of ultraviolet radiation on pathogenesis of the black leg of potato agent Dickeya solani. Plant Health. Research and Practice. 2017; (4):36 - 40.

37. Bagrov VV, Ivashkin AB, Gelaev IA, Kamrukov AS, Tumashevich KA, Alekseev YI, Mazurin ES, Panycheva YS, Yaremko AB. Biocidal efficiency of ultraviolet radiation regarding the excitant of the potato blackened stem Dickeya solani. International Journal of Green Pharmacy. 2017;11(4):S882—S886. Available from: doi: 10.22377/ijgp.v11i04.1421.

38. Al-Safadi B, Ayyoubi Z, Jawdat D. The effect of gamma irradiation on potato microtuber production in vitro. Plant Cell, Tissue and Organ Culture. 2000; 61(3):183-187. Available from: doi: 10.1023/A:1006477224536.

39. Li HZ, Zhou WJ, Zhang ZJ, Gu HH, Takeuchi Y, Yoneyama K. Effect of $\gamma$-radiation on development, yield and quality of microtubers in vitro in Solanum tuberosum L. Biologia Plantarum. 2005; 49(4): 625-628. Available from: doi: 10.1007/s10535-005-0062-1.

40. Salomón D, González C, Castillo H, Varela N. Effect of gamma rays on the germination of botanical potato seed (Solanum tuberosum L.). Cultivos Tropicales. 2017; 38(1):89—91.

41. Tikhonov AV, Derevyagina MK, Vasilyeva SV, Zeiruk VN. Radiological methods for treatment of potato tubers in storage. Zashchita katofelya. 2015; (1):22-25. (In Russ).

42. Matsuura-Endo C, Ohara-Takada A, Chuda Y, Ono H, Yada H, Yoshida M, et al. Effects of storage temperature on the contents of sugars and free amino acids in tubers from different potato cultivars and acrylamide in chips. Bioscience, Biotechnology, and Biochemistry. 2006; 70(5):1173 - 1180. Available from: doi: 10.1271/bbb.70.1173.

43. Frazier MJ, Kleinkopf GE, Brey RR, Olsen NL. Potato sprout inhibition and tuber quality after treatment with high-energy ionizing radiation. American Journal of Potato Research. 2006; 83(1):31-39. Available from: doi: 10.1007/BF02869607.

44. Alimov AS, Bliznuk UA, Borschegovskaya PY, Elansky S, Chernyaev AP, Yurov DS. Germination inhibition of potato tubers under the influence of the electron beam with energy of $1 \mathrm{Mev}$. Zashchita kartofelya. 2015; (1):26-29. (In Russ).

45. Rezaee M, Almassi M, Majdabadi Farahani A, Minaei S, Khodadadi M. Potato sprout inhibition and tuber quality after post harvest treatment with gamma irradiation on different dates. Journal of Agricultural Science and Technology. 2011; 13(6):829-842. Available from: doi: 10.15406/hij.2017.01.00005.

46. Mahto R, Das M. Effect of $\gamma$ irradiation on the physico-mechanical and chemical properties of potato (Solanum tuberosum L), cv. 'Kufri Chandramukhi' and 'Kufri Jyoti', during storage at $12{ }^{\circ} \mathrm{C}$. Radiation Physics and Chemistry. 2015; 107:12 - 18. Available from: doi: 10.1016/j.radphyschem.2014.08.021.

47. Dhali K, Basak N, Bhattacharya S. Effect of gamma irradiation on potato (Solanum tuberosum L.) tubers influencing post-harvest quality parameters. Journal of Crop and Weed. 2017; 13(2):129-135.

48. Avdyukhina VM, Bliznyuk UA, Borschegovskaya PY, Ilyushin AS, Levin IS, Studenikin FR, Chernyaev AP. Change of the kinetics of potato tuber sprouting after X-ray irradiation. Uchenye zapiski fizicheskogo fakul'teta. 2016; (3):163701. (In Russ). 
49. Afify AEMM, El-Beltagi HS, Aly AA, El-Ansary AE. Antioxidant enzyme activities and lipid peroxidation as biomarker compounds for potato tuber stored by gamma radiation. Asian Pacific Journal of Tropical Biomedicine. 2012; 2(3):S1548—S1555. Available from: doi: 10.1016/S2221-1691(12)60451-1.

50. Mahto R, Das M. Effect of gamma irradiation on the physico-mechanical and chemical properties of potato (Solanum tuberosum L.), cv. 'Kufri Sindhuri', in non-refrigerated storage conditions. Postharvest Biology and Technology 2014; 92: 37-45. Available from: doi: 10.1016/j.postharvbio.2014.01.011

51. Soares IG, Silva EB, Amaral AJ, Machado EC, Silva JM. Physico-chemical and sensory evaluation of potato (Solanum tuberosum L.) after irradiation. Anais da Academia Brasileira de Ciências. 2016; 88(2):941—950. Available from: doi: 10.1590/0001-3765201620140617.

52. Ezekiel R, Rana G, Singh N, Singh S. Physicochemical, thermal and pasting properties of starch separated from $\gamma$-irradiated and stored potatoes. Food Chemistry. 2007; 105(4):1420-1429. Available from: doi: 10.1016/j.foodchem.2007.05.018.

53. Lu ZH, Donner E, Yada RY, Liu Q. Impact of $\gamma$-irradiation, CIPC treatment, and storage conditions on physicochemical and nutritional properties of potato starches. Food Chemistry. 2012; 133(4):1188 - 1195. Available from: doi: 10.1016/j.foodchem.2011.07.028.

54. $\mathrm{Yu} \mathrm{Y,} \mathrm{Wang} \mathrm{J.} \mathrm{Effect} \mathrm{of} \gamma$ ray irradiation on starch granule structure and physicochemical properties of rice. Food Research International. 2007; 40(2):297-303. Available from: doi: 10.1016/j.foodres.2006.03.001.

55. Chung HJ, Liu Q. Molecular structure and physicochemical properties of potato and bean starches as affected by gamma-irradiation. International Journal of Biological Macromolecules. 2010; 47(2):214 -222. Available from: doi: 10.1016/j.ijbiomac.2010.04.019.

56. Marks N, Szecówka PS. Impact of variable magnetic field stimulation on growth of aboveground parts of potato plants. International Agrophysics. 2010; 24:165-170.

57. Vasilev AA, Polevik ND, Gordeev OV. The efficiency of pre-planting treatment of potato by electromagnetic field. Agro-food policy in Russia. 2015; (4):39-43. (In Russ).

58. Lysakov AA. Electromagnetic similarity of magnetic processing of potatoes. Agricultural Bulletin of Stavropol Region. 2015; (4):46-50. (In Russ).

59. Gordeev YA, Makarov NB. Preplant irradiation of potato tubers by low-temperature helium plasma. Plodorodie. 2009; (6):18-19. (In Russ).

60. Statsyuk NV, Kuznetsova MA, Rogozhin AN, Filippov AV. Pre-planting treatment with modulated pulse electric field as a tool to increase the productive potential of potato. Biotika. 2015; (3):10-12. (In Russ).

\section{INFORMATION ABOUT AUTHORS}

Kroupin Pavel Yuryevich - Candidate of Biological Sciences, Senior Researcher, Laboratory of Plant Pathogen Diagnostics, Russian Research Institute of Agricultural Biotechnology; Center of Molecular Biotechnology, Russian State Agrarian University-Moscow Timiryazev Agricultural Academy; e-mail: pavel-krupin@yandex.ru

ORCID https://orcidorg/0000-0001-6858-3941

eLibrary SPIN-code 3228-1320

Semenov Oleg Grigor'evich - Candidate of Biological Sciences, Professor, Department of Technosphere Safety, Agrarian-Technological Institute, RUDN University; e-mail: semenov_og@rudn.university eLibrary SPIN-code 4817-6577

\section{For citation:}

Kroupin PY, Semenov OG. Physical methods of pre-planting and postharvest treatment of potato: a review. RUDN Journal of Agronomy and Animal Industries, 2018, 13 (4), 383-395. doi: 10.22363/2312-797X-2018-13-4-383-395. 


\title{
ФИЗИЧЕСКИЕ МЕТОДЫ ПРЕДПОСАДОЧНОЙ И ПОСЛЕУБОРОЧНОЙ ОБРАБОТКИ КАРТОФЕЛЯ: ОБ3ОР
}

\author{
П.Ю. Крупин ${ }^{1,2}$, О.Г. Семёнов ${ }^{3}$ \\ ${ }^{1}$ Российский государственный аграрный университет - \\ МСХА имени К.А. Тимирязева \\ Москва, 127550, Российская Федеращия \\ ${ }^{2}$ Всероссийский научно-исследовательский институт \\ сельскохозяйственной биотехнологии \\ Москва, 127550, Российская Федерачия \\ ${ }^{3}$ Российский университет дружбы народов \\ Москва, 117198, Российская Федерация \\ pavel-krupin@yandex.ru
}

\begin{abstract}
Картофель является важной продовольственной культурой. Правильная предпосадочная и послеуборочная обработка клубней позволяет получить высокий урожай и избежать потерь при хранении. Среди различных методов обработки картофеля особое положение занимают физические методы: тепловая обработка горячей водой и паром, ультрафиолетовое (в том числе широкополосное) и гамма-облучение, обработка магнитными и электромагнитными полями (в том числе сверхвысокочастотными). Большинство физических методов относительно безвредны для окружающей среды и могут быть использованы без специальной регистрации и развивающимися странами. В статье впервые проведен обзор научных статей за последние 35 лет, посвященных физическим методам обработки картофеля (включая патенты на изобретения). Обзор научных статей показал перспективность данного направления как для предпосадочной, так и послеуборочной обработки картофеля. Физическая обработка оказывает воздействие на биохимический, клеточный и физиологический статус картофеля. Методы физической обработки позволяют контролировать фитопатогены, а отдельные методы (ультрафиолетовая, гамма-радиация) даже способны повышать иммунные свойства. Основные параметры клубней картофеля, на которые влияют методы физической обработки, - это прорастание глазков (стимуляция или ингибирование), поражение гнилью и черной ножкой, содержание крахмала, редуцирующих сахаров и аскорбиновой кислоты. Реакция клубней картофеля на методы физической обработки зависит от дозы, даты обработки, сроков и температуры хранения, агротехники и сорта. Низкие дозы обработки могут оказаться неэффективными, а слишком высокие могут привести к повреждению или гибели клеток и снижению иммунитета, а в конечном счете к развитию заболеваний. Слишком ранняя обработка может повредить клубень, так как после уборки ему необходимо пройти процесс суберинизации (заживления); при слишком поздней требуется повышение доз. При выборе метода физической обработки необходимо тщательно оптимизировать указанные параметры для конкретных условий хранения и сорта.
\end{abstract}

Ключевые слова: картофель, физическая обработка, гидротермическая обработка, пар, ультрафиолет, ксеноновая лампа, гамма-облучение, электромагнитные микроволны, фитопатоген

\section{Для цитирования:}

Крупин П.Ю, Семёнов О.Г. Физические методы предпосадочной и послеуборочной обработки картофеля: обзор // Вестник Российского университета дружбы народов. Серия: Агрономия и животноводство. 2018. Т. 13. № 4. С. 383-395. doi: 10.22363/2312-797Х-2018-13-4-383-395. 